revolutionary, and it might be advisable to await the result, before making generalizations of this sort.

I do not think that the Dunalastair belt of Grey Schist and Limestone, etc., to the north of the Tummel, is in the centre of a synform, nor that it is bounded to the east by a strip of Banded Group. My own field maps seem here to be widely different from those of the authors. The appearance of regularity which has been given to the outcrops of the different formations within this belt is, in my opinion, deceptive. Nor do I think that the authors have understood the structure of this part of Perthshire so thoroughly as to be able to claim that they have made " an important advance on Anderson's position".

E. M. Anderson.

\title{
ZONAL POSITION OF THE ELSWORTH ROCK.
}

Str,--I would like to ask Dr. Spath for the reference to any previous publication of the main thesis of my article (since he asserts it contains nothing much that is new): namely, that at Elsworth two distinct zones (cordatus and plicatilis) are represented, unmixed, in condensed ironshot facies, that the Elsworth Rock belongs to the plicatilis zone only, that the ironshot rock at Upware belongs only to the cordatus zone, and so is not the Elsworth Rock-equivalent, which at Upware is the Coralline Oolite. The passages I have quoted from the Cutch Memoir show that Dr. Spath regarded the ironshot rock at Upware as the Elsworth Rock, and the Elsworth Rock as containing a mixed or derived fauna.

Certainly the zonal position of the Elsworth Rock (at Elsworth) as given in Dr. Spath's memoir is unassailable, and it has not been assailed. In this particular his correlation agrees with that of his predecessors, Rigaux, Wedd, and myself.

Dr. Spath, without attempting to justify it, brings against me a serious charge of making "an entirely one-sided and misleading selection of passages and species and even dates of publication ", only to use them as skittles. In my article only two passages from his work are quoted. They are consecutive passages and are quoted en bloc, without expurgations. The quotations form a natural part of the introductory review of previous work, in order of dates of publication. They are the only passages that are relevant to the matter in hand. No species are "selected ", for none are omittedunless Dr. Spath is suggesting that I ought to have reprinted his separate list of thirty-nine species from Elsworth and St. Ives. Believing 72 per cent of those items to stand in need of alteration, I considered it preferable only to refer to it and give my new list.

University Museum, W. J. ARKELL.

OXFORD.

8th December, 1937. 